\title{
次世代型押出成形 CAE システム「SUNDYXTRUD」
}

\section{1.はじめに}

2002 年夏，弊社では押出成形プロセスにおける熱流動 現象を評価し，ダイ設計や成形条件の最適化を支援する新 しい押出成形 CAE システム「SUNDYXTRUD（サンディ エクストゥルード)」を開発・販売開始したので紹介する.

\section{2. 解 析機能}

\section{1 ）三次元ダイ内熱流動解析機能}

三次元の有限要素法（FEM）熱流動解析機能をベース としている．計算安定性と計算速度向上のため直接法マト リクスソルバーの導入, 異種要素の自由結合を許す Superimposition 法を採用し，パソコン上で大規模解析を実現可 能としている.

\section{2 ）異型押出解析機能}

ダイ流出後の自由表面評価を含む三次元異型押出解析機 能がある. ALE 法を利用した押出物形状予測, 多層押出, 多層コーティング解析も可能.

3 ）簡易解析機能

発達流れを仮定してダイ断面内熱流動場を二次元簡易解

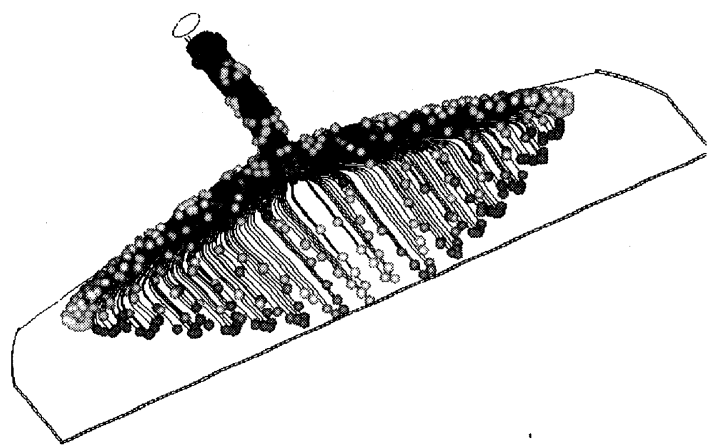

図 1 コートハンガーダイ流動解析（粒子トレース図）

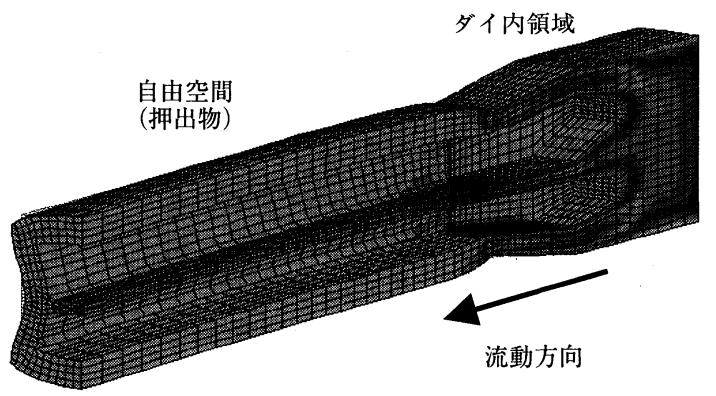

図 2 異型押出解析（流速分布，押出物形状）
析する機能がある．粘弾性法線応力の評価，回復性ひずみ, スウェルを評価して押出物断面形状の予測も可能.

\section{4) 最適化解析機能}

本システムは従来型の計算機支援シミュレーション (CAE) から，計算機支援最適化（CAO）への進化を目指 し, 次世代型押出成形解析システムと称している。特に, 応答曲面法 (RSM) を利用したダイ形状や成形条件の最 適化解析機能により成形技術の革新が期待されている. な お, 本最適化解析機能は, 東京工業大学大学院理工学研究 科の轟章助教授との共同研究によるものである.

\section{3.おわりに}

これまで，押出成形技術は，非常にデリケートで経験や 勘，試作作業などに依存せざるをえずCAEが浸透しにく い分野だとされてきた.しかしながら，「SUNDYXTRUD」 は, 以下のような特徵を持つ次世代型押出成形 CAE であ り，今後の普及が期待されている.

(1)押出成形の用途に応じた利用が可能.

(2)成形技術者・設計技術者が手軽に利用できる。

(3)ダイ形状や成形条件の最適化支援機能.

(4)コストパフォーマンスの良さ.

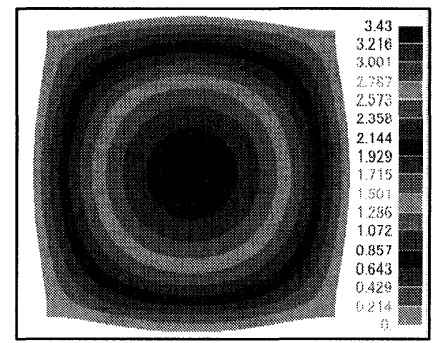

図 3 正方形ダイの押出解析（流速分布と変形図）

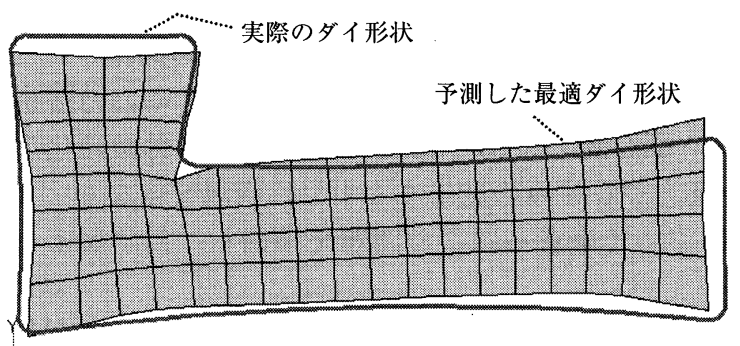

図 4 L 字型押出物形状をえるためのダイ形状 (実際のダイ形状と最適化解析の比較)

\footnotetext{
Yoshikawa, Hideo (秼)プラメディア 常務取締役 東京都中野区本町 4-44-18（テ164-0012） 2002.8. 1 受理
} 